\title{
Environmental Economics
}




\section{MACMILLAN TEXTS IN ECONOMICS}

Macmillan Texts in Economics is a new generation of economics textbooks from Macmillan developed in conjunction with a panel of distinguished editorial advisers:

David Greenaway, Professor of Economics, University of Nottingham Gordon Hughes, Professor of Political Economy, University of Edinburgh David Pearce, Professor of Economics, University College London David Ulph, Professor of Economics, University College London

\section{PUBLISHED}

Public Sector Economics: Stephen J. Bailey

Understanding the UK Economy (3rd edition): Edited by Peter Curwen

Business Economics: Paul R. Ferguson, Glenys J. Ferguson and R. Rothschild

Environmental Economics in Theory and Practice: Nick Hanley, Jason F. Shogren and Ben White

International Finance: Keith Pilbeam

Economics of the Labour Market: David Sapsford and Zafiris Tzannatos

\section{Series Standing Order}

If you would like to receive future titles in this series as they are published, you can make use of our standing order facility. To place a standing order please contact your bookseller or, in case of difficulty, write to us at the address below with your name and address and the name of the series. Please state with which title you wish to begin your standing order. (If you live outside the United Kindgom we may not have the rights for your area, in which case we will forward your order to the publisher concerned.)

Customer Services Department, Macmillan Distribution Ltd Houndmills, Basingstoke, Hampshire RG21 6XS, England 


\title{
ENVIRONMENTAL ECONOMICS IN THEORY AND PRACTICE
}

\author{
Nick Hanley \\ University of Stirling \\ Jason F. Shogren \\ University of Wyoming \\ and \\ Ben White
}

University of Newcastle upon Tyne

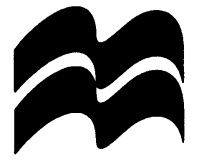


(C) Nick Hanley, Jason F. Shogren and Ben White 1997

All rights reserved. No reproduction, copy or transmission of this publication may be made without written permission.

No paragraph of this publication may be reproduced, copied or transmitted save with written permission or in accordance with the provisions of the Copyright, Designs and Patents Act 1988, or under terms of any licence permitting limited copying issued by the Copyright Licencing Agency, 90 Tottenham Court Road, London W1P 9HE.

Any person who does any unauthorised act in relation to this publication may be liable to criminal prosecution and civil claims for damages.

First published 1997 by

MACMILLAN PRESS LTD

Houndmills, Basingstoke, Hampshire RG21 6XS

and London

Companies and representatives

throughout the world

ISBN 978-0-333-58235-0 hardcover

ISBN 978-0-333-58236-7

ISBN 978-1-349-24851-3 (eBook)

DOI 10.1007/978-1-349-24851-3

A catalogue record for this book is available from the British Library

This book is printed on paper suitable for recycling and made from fully managed and sustained forest sources.

$\begin{array}{llllllllll}10 & 9 & 9 & 7 & 6 & 5 & 4 & 3 & 2 & 1\end{array}$

$\begin{array}{llllllllll}06 & 05 & 04 & 03 & 02 & 01 & 00 & 99 & 98 & 97\end{array}$

Typeset in Great Britain by

Aarontype Limited, Bristol, England 


\section{Contents}

List of Figures $\quad$ ix

List of Tables xii

Introduction xiii

Acknowledgements $\quad$ xv

1 The Economy and the Environment:

Two Parts of a Whole 1

1.1 Introduction 1

1.2 Interlinkages between the economy and the environment 2

$\begin{array}{ll}1.3 & \text { The first two laws of thermodynamics } \\ 11\end{array}$

$\begin{array}{lll}1.4 & \text { Conclusions } & 13\end{array}$

Technical note: game theory 14

2 Market Failure $\quad 22$

$\begin{array}{ll}2.1 & \text { Introduction } \\ 2.22\end{array}$

2.2 Incomplete markets 24

$\begin{array}{lll}2.3 & \text { Externalities } & 29\end{array}$

$\begin{array}{lll}2.4 & \text { Non-exclusion and the commons } & 37\end{array}$

$2.5 \quad$ Non-rivalry and public goods $\quad 42$

$\begin{array}{lll}2.6 & \text { Non-convexities } & 46\end{array}$

2.7 Asymmetric information 49

2.8 Concluding comments 56

3 Economic Incentives for Environmental Protection:

$\begin{array}{lr}\text { An Overview } & 58\end{array}$

3.1 Introduction $\quad 58$

$\begin{array}{ll}3.2 & \text { Price rationing: charges and subsidies }\end{array}$

3.3 Liability rules: non-compliance fees, bonds, and

3.4 Quantity rationing: marketable permits 87

$\begin{array}{lll}3.5 & \text { Evaluative criteria } & 91\end{array}$

3.6 Practical conditions for use of economic incentives 95

$\begin{array}{lll}3.7 & \text { Concluding remarks } & 97\end{array}$

Technical note: mathematical programming 98 
4 Pollution Taxes for the Efficient Control of Pollution 106

4.1 Introduction 106

4.2 Efficiency properties of a tax on emissions 107



$\begin{array}{lll}4.4 & \text { Conclusions } & 128\end{array}$

5 Tradeable Pollution Permits 130

5.1 Introduction 130

5.2 The basic theory of tradeable pollution permits 130

5.3 Research issues in tradeable permit markets 139

5.4 Conclusions 155

6 Transboundary Pollution Problems 159

6.1 Introduction 159

6.2 Transboundary pollution as a problem of international externalities 163

6.3 Transboundary pollution and game theory 166

$\begin{array}{lll}6.4 & \text { Conclusions } & 173\end{array}$

7 An Introduction to the Economics of Natural

Resource Exploitation $\quad 177$

$\begin{array}{lll}7.1 & \text { Introduction } & 177\end{array}$

$\begin{array}{lll}7.2 & \text { Elementary capital theory } & 179\end{array}$

7.3 The maximum principle of optimal control theory 182

7.4 The application of the maximum principle to specific $\begin{array}{ll}\text { fishery management problems } & 189\end{array}$

7.5 The discrete-time maximum principle and dynamic $\begin{array}{ll}\text { programming } & 202\end{array}$

7.6 Wiener processes, Itô's processes and stochastic calculus 206

$\begin{array}{lll}7.7 & \text { Conclusions } & 214\end{array}$

8 Natural Resources: Types, Classification and Scarcity 216

8.1 Natural resource types and classification 216

$\begin{array}{ll}8.2 & \text { Measuring resource scarcity } \\ 8.317\end{array}$

$\begin{array}{lll}8.3 & \text { Conclusions } & 225\end{array}$

9 An Economic Analysis of Non-renewable

Natural Resources $\quad 227$

9.1 Introduction 227

9.2 Market structure and the exploitation of
non-renewable resources 
9.3 Production technology and extraction costs 248

9.4 Applying the theory 258

9.5 Government policy towards non-renewable

9.6 Uncertainty and the rate of resource extraction 266

9.7 Summary 270

10 Renewable Resource Economics 274

10.1 Introduction 274

10.2 Population growth models 276

10.3 Static models of fishery exploitation in continuous time 281

10.4 Static economic models of fisheries 286

10.5 Comparative dynamic models of fishing 288

10.6 Fisheries policy 298

10.7 Applying the theory and the discrete-time model 303

10.8 Extending the theoretical model 308

10.9 Strategic behaviour in fishery management 313

10.10 Fishing under uncertainty 325

10.11 Summary 332

11 The Economics of Forestry Exploitation 335

11.1 Introduction 335

11.2 The principles of commercial forestry economics 336

11.3 Multi-use forestry and the socially optimal forest rotation 340

11.4 Forestry land use and agriculture 343

11.5 Forest policies 350

11.6 The optimal forest rotation under uncertainty 352

11.7 Summary 354

12 The Theory of Non-market Valuation 356

12.1 Introduction 356

12.2 Measures of economic value 357

12.3 Valuing risk and ex ante measures of value 368

12.4 Issues in non-market valuation 372

12.5 Concluding comments 381

13 Methods for Valuing Environmental Costs and Benefits

13.1 Introduction 383

13.2 Direct methods of valuation 384

13.3 Indirect methods of valuation 404

13.4 Summary 418 
14 The Economics of Sustainable Development 425

$\begin{array}{lll}14.1 & \text { Introduction } & 425\end{array}$

14.2 Possible sustainability rules 426

14.3 Indicators of sustainability 433

14.4 The Common-Perrings model of sustainable development 443

$\begin{array}{ll}\text { Index } & 451\end{array}$ 


\section{List of Figures}

1.1 Economy-environment interactions 3

1.2 Possible damage functions 4

1.3 Energy use to GDP ratios in four countries 9

$\begin{array}{ll}\text { T.1 Nash equilibrium } & 19\end{array}$

T.2 Stackleberg equilibrium 20

2.1 Socially optimal level of pollution 26

2.2 Alternative socially optimal levels of pollution 27

2.3 Socially and privately optimal level of pollution 30

2.4 Co-operative and non-co-operative self-protection 35

2.5 Total cost of co-operative and non-co-operative

2.6 Open access and the prisoners' dilemma 41

2.7 Co-ordination game 42

2.8 Pure public goods 46

2.9 Single-peaked net benefit curve 47

2.10 Non-convex marginal costs 47

2.11 Non-convexity and the optimal level of pollution 48

2.12 Multi-peaked net benefit curve 49

2.13 Environmental shirking 50

2.14 Moral hazard 52

2.15 Feasible insurance contracts given moral hazard 53

2.16 Quantity rationing of insurance 54

2.17 Adverse selection 55

3.1 Socially optimal level of pollution control 59

3.2 Privately and socially optimal levels of output 63

3.3 Charges given uncertainty 65

3.4 Optimal levels of output given ambient charge 70

3.5 Short and long run impacts of a pollution tax $\quad 74$

3.6 Short and long run impacts of a pollution subsidy 75

3.7 Asymmetric information and an environmental subsidy 77

$\begin{array}{lll}3.8 & \text { Subsidy paid ignoring information rents } & 78\end{array}$

3.9 Subsidy paid accounting for information rents 79

3.10 Quantity rationing under uncertainty $\quad 89$

3.11 Mixed incentive system 91

4.1 Marginal abatement costs for a firm 109

4.2 An efficient tax on emissions 112

4.3 Savings under innovation with a pollution tax 119 
4.4 Savings under innovation, diffusion and regulatory response

4.5 Financial burden of a pollution tax

4.6 A possible time path for a stock pollutant

5.1 Firm's optimal response to a permit scheme

5.2 Supply and demand for permits

5.3 Permit revenues and expenditures

5.4 Innovation in permit markets

6.1 Non-co-operative and full co-operative outcomes

7.1 Logistic growth curve

7.2 A phase-plane diagram

7.3 Trajectory types

7.4 Phase-plane diagram showing stability analysis

7.5 Comparative dynamics and the steady-state solution

7.6 A dynamic programming problem

7.7 Fishery investment under uncertainty

8.1 Problems of defining 'reserves'

8.2 The mineralogical threshold

9.1 Comparative dynamics for costless extraction under competition and monopoly

9.2 Monopoly rent, current value

9.3 Monopoly rent, present value

9.4 Price path for the Nash-Cournot solution to the cartel problem

9.5 Quantity path for the Nash-Cournot solution to the cartel problem

9.6 Von Stackelberg equilibrium 242

9.7 Extraction costs 249

9.8 Time paths for the shadow price of a resource 257

10.1 The logistic growth curve 277

10.2 Growth curve showing depensation 278

$\begin{array}{ll}10.3 & \text { A simple population cycle } \\ & 279\end{array}$

10.4 Ricker curves 280

10.5 The effect of harvesting on population change 281

10.6 Equilibrium between fishing effort and the stock 283

10.7 Equilibrium between fishing effort and the catch 283

10.8 Equilibrium between fishing effort and the stock with critical depensation

10.9 Equilibrium between fishing effort and the catch with critical depensation

10.10 Static fishing equilibria 287

10.11 Equilibrium stock and the number of firms 294

10.12 Equilibrium shadow price against the number of firms 294 
10.13 Phase-plane representation of the sole-ownership fishery with an endogenous price

10.14 Bioeconomic equilibrium in the harp seal population 306

10.15 Optimal harvest and investment

10.16 Pay-off sets

10.17 Pay-off possibility sets

$\begin{array}{ll}10.18 \text { Nash bargaining solution } & 317\end{array}$

10.19 Steady-state equilibria in a fish war 324

10.20 Stochastic stock recruitment 331

11.1 Tree growth function 336

11.2 Comparative statics for the Faustmann rotation 339

11.3 Grazing benefit function 342

11.4 Optimal Hartman rotation 343

11.5 The effect of a yield tax on the Faustmann rotation 351

12.1 Preferences, utility and consumer surplus 358

12.2 WTP for improved environmental services 361

12.3 WTP and WTA given perfect and imperfect substitutability

12.4 WTP and WTA measures of value, given an environment hazard

12.5 Value formation and preference learning 377

13.1 Hedonic price measures of value 412

14.1 Sustainability versus efficiency 433 


\section{List of Tables}

4.1 Water quality levels and resource costs 110

4.2 Control costs for air pollution 118

4.3 Tax rates on greenhouse gases 123

4.4 Natural parameters for greenhouse gases 123

5.1 Abatement costs and emission reductions under different offset rules $\quad 141$

5.2 Cost savings under sequential trading 149

7.1 Conditions for stability in systems of differential equations 196

8.1 World reserves, reserve bases and crustal abundances of selected minerals $\quad 220$

9.1 Studies of non-renewable resource scarcity 255

9.2 Estimates for the output equation 262

10.1 The bionomic optimum 307

10.2 Pay-off matrix 314

13.1 Effects of more information on WTP to preserve heaths 397

13.2 Description of variables for analysis 410

13.3 Determinants of real consumer surplus per unit of use 411

13.4 Demand curve for broadleaved woods 415 


\section{Introduction}

This book is aimed at final-year undergraduates in environmental and resource economics, graduate students and professionals. It provides a guide to the most important areas of natural resource and environmental economics: the economics of non-renewable and renewable resource extraction, the economics of pollution control, the application of costbenefit analysis to the environment and the economics of sustainable development. However we cannot claim that all interesting areas of the subject are represented here. For example, the reader will find very little on distributional issues, on trade and the environment, or recycling and solid waste management. Reasons for omissions include the size and cost of the resultant volume. We have, instead, concentrated on those parts of theory which we find most interesting and have tried to show how this theory can be applied to real-world problems. Thus, for example, Chapter 12 considers the theory of environmental valuation, while Chapter 13 explains how valuation is actually done.

Throughout the book, results are presented in words, in figures and more formally using mathematical models. To aid this exposition, brief 'technical notes' inform readers about the Kuhn-Tucker conditions, game theory and linear programming. The book progresses through the laws of thermodynamics to an analysis of market failure. The economics of pollution control are then considered. Natural resources are the subject of the next section, and the book closes with an examination of environmental costbenefit analysis and sustainable development.

All of the authors have been involved in teaching courses in environmental and natural resource economics to both undergraduates and graduates in Britain and North America, so we hope that some benefit has been gained from this experience which will in turn aid readers of this book. We have also sought to include material from areas of our own research, emphasising the beneficial links between teaching and research.

This book started life in 1991, and so has been a long time in the making. We would therefore first like to thank Stephen Rutt of the Macmillan Press for his patience and fortitude. Vic Adamowicz deserves a very big thankyou for reading over many draft chapters and providing comments: thanks, Vic. Nick Hanley also would like to thank many people for helpful comments on draft chapters, and for trying to explain the subject to him. In no particular order, these people include Mick Common, Charles Perrings, Jim Shortle, John Hartwick, David Pearce, Kerry Turner, Jack Pezzey, 
Alistair Munro, John Haynes and Clive Spash. Thanks also to Paul Gill for the box sections in Chapter 14, David Parsisson for drawing Nick's diagrams on his Apple and Jenny Milne for compiling the contents pages. Finally, thanks to Fanny Missfeldt for co-authoring Chapter 6 with me. Jay Shogren would like to thank Tom Crocker, Bruce Forster, Todd Sandler and Joe Kenkuliet. Ben White would like to thank Tim Masters for reading parts of his section and Caroline Saunders for useful discussions on nonrenewable resources, Caroline Faddy for secretarial assistance and his wife Jane for encouragement and support.

This book is dedicated to our families: Kate, Rose and Charlie; Deb, Riley and Maija; and Jane, Catherine and Steven. 


\section{Acknowledgements}

The authors and publishers wish to thank the following for permission to use copyright material:

Academic Press, Inc. for Figure 4.4 from Scott Milliman and Raymond Prince (1989) 'Firm incentives to promote technical change in pollution control', Journal of Environmental Economics and Management, 17, pp. 245-65; and Figure 3.4 adapted from R. Cabe and J. Herriges (1992) 'The regulation of non-point sources of pollution under imperfect and asymmetric information', Journal of Environmental Economics and Management, 22, 134-46;

American Agricultural Economic Association for Tables 13.2 and 13.3 from V.K. Smith and W. Kauru (1990) 'Signals or noise? Explaining the variation in recreation benefit estimates', American Journal of Agricultural Economics, May, 419-33;

American Scientist for Figure 8.2 from B. Skinner (1976) 'A second ironage?', American Scientist, 64, 258-269;

Kluwer Academic Publishers for Tables 4.3 and 4.4 from P. Michaelis (1992) 'Global warming: efficient policies in the case of multiple pollutants', Environmental and Resource Economics, 2, 61-78.

Every effort has been made to trace all the copyright-holders, but if any have been inadvertently overlooked the publishers will be pleased to make the necessary arrangement at the first opportunity. 